\title{
A new species of Neckera (Neckeraceae, Bryopsida) from Xizang, China
}

\section{Enroth, Johannes}

2007

Enroth , J \& Ji , M 2007 , ' A new species of Neckera (Neckeraceae, Bryopsida) from Xizang,

China ' , Edinburgh journal of botany , vol 64 , no. 3 , pp. 295-301.

http://hdl.handle.net/10138/23924

Downloaded from Helda, University of Helsinki institutional repository.

This is an electronic reprint of the original article.

This reprint may differ from the original in pagination and typographic detail.

Please cite the original version. 


\title{
A NEW SPECIES OF NECKERA (NECKERACEAE, BRYOPSIDA) FROM XIZANG, CHINA
}

\author{
J. ENROTH ${ }^{1} \& \mathrm{M} \cdot \mathrm{JI}^{2}$
}

\begin{abstract}
A new species of Neckeraceae, Neckera serrulatifolia Enroth \& M.Ji, is described from Xizang (Tibet), China. It belongs in an Asian group of relatively robust, distinctly stipitate species with an obtuse leaf apex, relatively long costa and strongly incrassateporose leaf cell walls, but differs from the other species by the combination of strongly complanate and undulate branch leaves, long leaf decurrencies, and serrulate margins at leaf base and at midleaf. The sporophytes remain unknown.
\end{abstract}

Keywords. Mosses, Neckera, Neckeraceae, new species, taxonomy.

\section{INTRODUCTION}

Neckeraceae is a moss family whose centre of diversity is in subtropical and tropical Asia. The senior author has studied the taxonomy of the family for more than two decades, concentrating on the tropical taxa, especially from Asia. Taxonomic novelties are still being discovered; a recent example is the genus Shevockia, described by Enroth \& Ji (2006).

Neckera is estimated to contain c.50 species worldwide. Its centre of diversity lies in Asia, especially in the Himalayan region (broadly conceived) and China. The junior author's taxonomic work on the Asian and Australasian species has so far led to two published papers (Ji et al., 2005; Ji \& Enroth, 2006), including a description of a new species from Nepal. There remain new species to be described from China, of which one is presented here.

The specimen on which this report is based was kindly communicated to us for examination by Mr Jürgen Kluge and is a duplicate from the personal herbarium of Prof. Georg Miehe (Marburg, Germany). Since the 1980s Prof. Miehe has collected plants extensively in the Himalayan region, and several new taxa, including mosses, have been described from his specimens (e.g. Ochyra, 1989, 1990).

\section{Neckera serrulatifolia Enroth \& M.Ji, sp. nov. Figs 1, 2.}

Haec species $N$. crenulatae aliquantum proxima, foliis omnibus magis valde undulatis, foliis praecipue ramulorum valde complanatis (haud erecto-patentibus), margine foliorum ad basim mediumque clare serrulato (non subintegris) differt.

\footnotetext{
${ }^{1}$ Department of Biological and Environmental Sciences and the Botanical Museum, PO Box 7, 00014 University of Helsinki, Finland. E-mail: johannes.enroth@helsinki.fi

2 School of Landscape Architecture, Zhejiang Forestry College, Lin'an, Zhejiang 311300, China.
} 


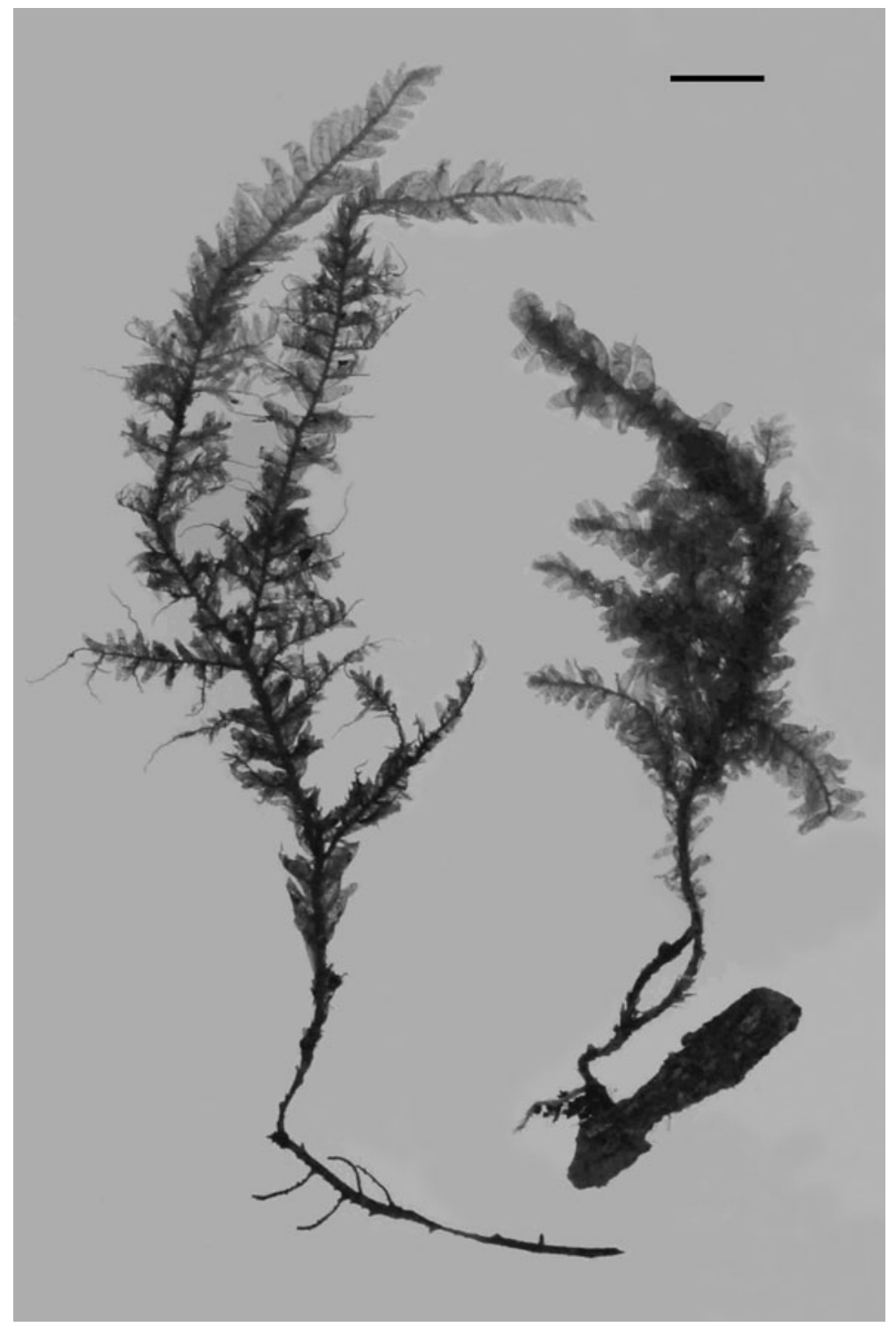

FIG. 1. Habit of Neckera serrulatifolia Enroth \& M.Ji (from the holotype). Scale bar $=0.5 \mathrm{~cm}$.

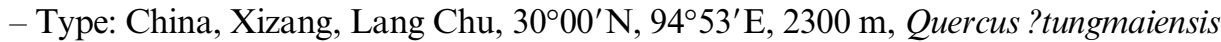
forest on left bank of lower Lang Chu, 23 viii 1994, G. Miehe \& U. Wündisch 10112:14 (holo H; iso herb. G. Miehe).

Plants gregarious, green to somewhat dirty-green, slightly glossy, stems to c.6 cm long, irregularly to subpinnately branched, frondose, short-stipitate. Many branch tips naked due to caducous distal branch leaves. Stolons creeping, bearing small, bleached 


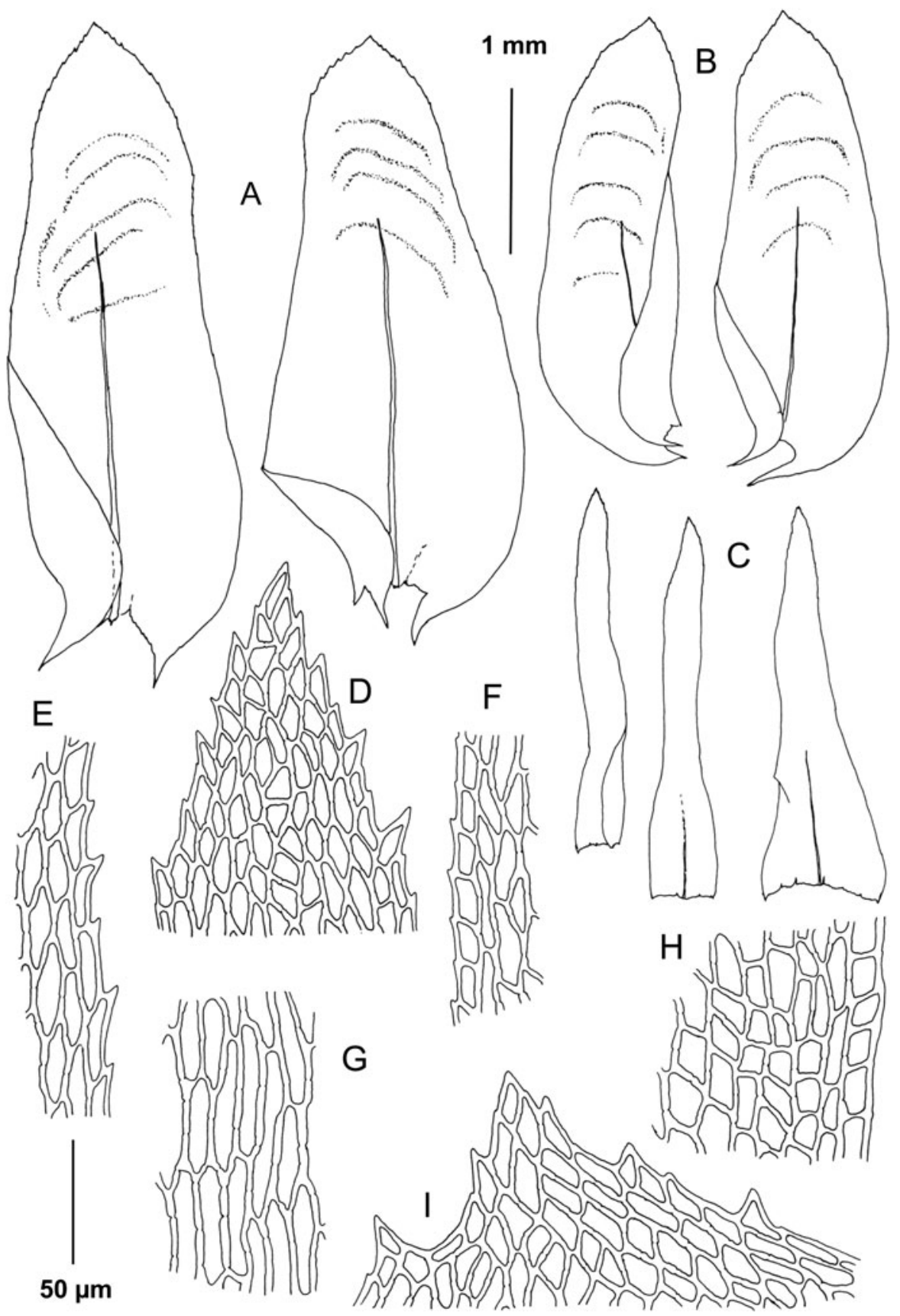

FIG. 2. Neckera serrulatifolia Enroth \& M.Ji (from the holotype). A, two stem leaves; B, two branch leaves; C, three pre-fertilization perichaetial leaves; D, apex of a pre-fertilization perichaetial leaf; E, stem leaf margin at midleaf; F, stem leaf margin near leaf base; G, median laminal cells of stem leaf; $\mathrm{H}$, cells in alar region of stem leaf; I, stem leaf apex. Scale bars: $1 \mathrm{~mm}$ (A-C), $50 \mu \mathrm{m}(\mathrm{D}-\mathrm{I})$. 
and appressed leaves (mostly eroded off in this specimen). Rhizoids in tufts situated just below leaf insertions, brownish-orange, unbranched or very scarcely branched, smooth. Stipe leaves relatively few, appressed, (broadly) ovate-acute, proximal ones ecostate, in upper parts of stipe grading in shape to stem leaves. Stipe cross-section elliptic, epidermal and cortical cells small and thick-walled, cortex 5-7 cell layers thick; medullary cells larger and thinner-walled, central strand none. Stem leaves and branch leaves complanate-spreading, strongly undulate. Stem leaves to c. $4.0 \mathrm{~mm}$ long and $1.6 \mathrm{~mm}$ wide near leaf base, somewhat asymmetrically ovate-lingulate from a longdecurrent base, apex obtuse-mucronate to broadly acute; costa single and reaching to $1 / 2-3 / 4$ leaf length, occasionally bifurcate and shorter, often more or less spurred; margins faintly serrulate near base, becoming progressively more so upwards, apex serrate by uni- to multicellular teeth. Leaf cells smooth, walls relatively thick and porose nearly throughout lamina; apical cells rhombic to elliptic, 15-25 $\times 10-12 \mu \mathrm{m}$, median cells linear with blunt ends, 40-70 $\times 8-10 \mu \mathrm{m}$, basal cells linear with blunt ends or nearly rectangular, $60-90 \times 8-10 \mu \mathrm{m}$; laminal cells becoming shorter towards margins, where often rectangular or (sub)quadrate especially in leaf base; cells at leaf insertion often greyish-yellow and thicker-walled than supradjacent laminal cells, walls strongly porose; alar cells forming a fairly distinct group just above decurrency, shorter than adjacent inner laminal cells, quadrate to elliptic or irregular, often greyish; decurrency cells again longer. Branch leaves similar but smaller, to $2.5 \times 1.0 \mathrm{~mm}$. Branch primordia covered by embryonic leaves; pseudoparaphyllia numerous, filiform and uniseriate to wider and multiseriate, length variable, to c. $400 \mu \mathrm{m}$ long.

Presumably dioecious (male gametoecia not seen). Perichaetia several on some stems, lacking on others; inner perichaetial leaves to c. $2.8 \mathrm{~mm}$ long, from an ovate base at c. $1 / 3$ of leaf length narrowed to a long-ligulate, nearly straight acumen with an acute tip; costa single or bifurcate, reaching to c. $1 / 2$ of leaf length; margins distinctly serrate by unicellular teeth near leaf tip; marginal cell row differentiated at leaf base and midleaf, consisting of quadrate to rectangular, mostly hyaline cells; archegonia c. $0.6 \mathrm{~mm}$ long; paraphyses numerous, hyaline, filiform. Sporophytes and the associated gametophytic structures (vaginulae, calyptrae) unknown.

Neckera serrulatifolia belongs in a peculiarly Asian group of relatively robust and distinctly stipitate Neckera species with relatively long costae and strongly incrassate-porose leaf cell walls (see Enroth, 1996). The other species in the group are Neckera yunnanensis Enroth (endemic to Yunnan, China), N. undulatifolia (Tix.) Enroth (N Vietnam, Philippines; Enroth, 1992a, 1996), N. polyclada Müll.Hal. (Japan, several provinces in China, Bhutan; Enroth, 1994; Redfearn et al., 1996), N. warburgii Broth. (Philippines, Borneo; Enroth, 1994), N. crenulata Harv. (Himalayan region, Yunnan, Taiwan) and N. perpinnata Card. \& Thér. (endemic to Guizhou, China).

Neckera serrulatifolia is most similar to $N$. crenulata, which is at least locally frequent in the Himalayan region. Neckera serrulatifolia has more strongly undulate and more strongly complanate leaves, especially branch leaves (in $N$. crenulata they are not at all complanate but rather erect-spreading), and the apical branch leaves 
are often caducous, leaving the branch tips naked. The leaves are also more distinctly asymmetric, have narrower apices, and clearly more strongly serrulate margins at leaf base and midleaf (nearly entire in $N$. crenulata). The marginal leaf cells in $N$. crenulata are longer than in $N$. serrulatifolia. Neckera perpinnata, which is known only from the type specimen from Guizhou (isotype H-BR), resembles the fairly variable $N$. crenulata in many respects and is distinguished mainly by the more acute leaf tips and wider leaf bases.

The caducous distal branch leaves and long leaf decurrencies are characters that Neckera serrulatifolia shares with $N$. polyclada (see Noguchi, 1989). Otherwise the two species are quite different: the leaves of the latter are concave, not complanate, much less strongly undulate and the leaf margins are entire below and less strongly toothed above. Neckera polyclada also has scattered paraphyllia, while $N$. serrulatifolia lacks paraphyllia altogether.

Neckera yunnanensis, described by Enroth (1996), clearly differs from $N$. serrulatifolia by the non-decurrent leaf bases and less strongly toothed leaf margins below midleaf. Neckera undulatifolia and $N$. warburgii have a completely different leaf shape and erect-patent rather than complanate leaves.

Neckera himalayana Mitt., which is not very distinctly stipitate, also has more symmetric and less undulate leaves with only minutely serrulate apices compared with the distinctly toothed ones in $N$. serrulatifolia.

Gangulee's (1976) illustration of 'Neckera setschwanica' resembles $N$. serrulatifolia in many characters. He cited two specimens collected at $1700 \mathrm{~m}$ and $4000 \mathrm{~m}$ in Sikkim, India, and deposited in NICH. The illustration was based on specimen 'NICH 20150', which must be the one from $4000 \mathrm{~m}$; this specimen is no longer to be found in $\mathrm{NICH}$ (pers. comm. with the Curator). The herbarium number of the specimen from $1700 \mathrm{~m}$ is 201560; it represents Neckera crenulata and is clearly different from Gangulee's illustration of $N$. setschwanica. While the Himalayan specimens here referred to Neckera serrulatifolia share some morphological features with $N$. setschwanica (long costa, undulate leaves), there are several clear differences. The latter species, whose holotype (H-BR) we have examined, has much more sharply pointed and more asymmetric leaves, and scattered paraphyllia on the stems and branches. Neckera setschwanica is a Chinese endemic and known from the provinces of Guizhou, Henan and Sichuan (Redfearn et al., 1996).

Neckera serrulatifolia is known with certainty only from the type specimen from Xizang (Tibet). However, since it cannot be determined if Gangulee's (1976) illustration of ' $N$. setschwanica' based on a specimen from Sikkim, India, represents this taxon, there remains the possibility that it has at least a somewhat wider distribution in the eastern Himalayan region.

\section{Selected specimens examined}

Neckera crenulata. China. Yunnan. 'Fl. von China, Pe yen tsin (Yünnan)', leg. S. Fen, Winter 1920/21 (H-BR 2892009). Baoshan Co., Gaoligang Shan Range, 30 v 2005, James R. Shevock 
27202 (H). 'bois de Santchang-Kiou (Hokin) [...] 27. mars 1890', Delavay 4768bis (H-BR 2892013, isotype of Neckera brachyclada Besch.). India. Sikkim, Yoksam, 1700 m, 17 v 1960, 'Univ. Tokyo Bot. Exped. to Eastern India, leg. H. H., H. K., G. M., M. T. and T. T.' (NICH 201560).

Neckera himalayana. InDiA. Sikkim, Sinahul, 19 iv 1862, Wichura s.n. (H-BR 2892011). Tamil Nadu, Nilghiri Hills, 24 i 1973, C.C. Townsend 73/697 (pers. herb. J. Enroth, ex herb. C.C. Townsend).

Neckera perpinnata. China. 'Kouy-Tchéou: Pin-fa', 1905, Cavalerie 1611 p.p. (H-BR 2892010, ex herb. I. Thériot).

Neckera polyclada. JAPAN. Honshu, Tokyo-to, Nishimata-gun, Mt. Tenso, x 1980, U. Mizushima (H 3097649, Bryophyta Exsiccata, ed. Z. Iwatsuki \& M. Mizutani, Fasc. 4, no. 172).

Neckera setschwanica. ChinA. Sichuan. 'Prov. Setschwan austro-occid.: In montium Daliangschan (territorii Lolo) [...]', 25 iv 1914, Handel-Mazzetti Diar Nr. 3946 (H-BR 2892001, holotype). Wen-chuan Co., Wo-long Nature Reservation, 1981, J.-s. Lou 3443a (H 3097788).

Neckera undulatifolia. Type material, see Enroth (1992a).

Neckera warburgii. Type material, see Enroth (1992b). PhiliPPINES. 1980, 'Neckeraceae 26.1', without collector (B 30 0253856).

\section{ACKNOWLEDGEMENTS}

We thank Mr Jürgen Kluge (Marburg) and the Curators of NICH and B for sending us specimens for examination.

\section{REFERENCES}

Enroth, J. (1992a). Notes on the Neckeraceae (Musci). 14-16. The identities of Porothamnium undulatifolium and Baldwiniella tibetana, plus the second record of Neckeropsis touwii. Ann. Bot. Fenn. 28: 249-251.

Enroth, J. (1992b). Notes on the Neckeraceae (Musci). 13. Taxonomy of the genus Himantocladium. Ann. Bot. Fenn. 29: 79-88.

En Roth, J. (1994). Additions to the moss floras of Solomon Islands and several countries of tropical Asia. Trop. Bryol. 9: 25-30.

Enroth, J. (1996). Contributions to tropical Asian Neckeraceae (Bryopsida). Hikobia 12: 1-7.

Enroth, J. \& Ji, M. (2006). Shevockia (Neckeraceae), a new moss genus with two species from Southeast Asia. J. Hattori Bot. Lab. 100: 69-76.

GAngulee, H. C. (1976). Mosses of Eastern India and adjacent regions. Fasc. 5, Isobryales: 1135-1462. Published by the author, Calcutta.

Ji, M. \& Enroth, J. (2006). Notes on the Neckeraceae (Bryopsida), 23. The identity of Neckera tjibodensis. J. Bryol. 28: 167-169.

Ji, M., Enroth, J. \& Qiang, S. (2005). Neckera noguchiana (Neckeraceae, Bryopsida), a new species from Nepal. Ann. Bot. Fenn. 42: 391-393.

Noguchi, A. (supplemented by Z. Iw A TSU KI) (1989). Illustrated moss flora of Japan. Part 3: 493-742. Hattori Botanical Laboratory, Nichinan. 
Ochy RA, R. (1989). Miehea himalayana, a new species and genus of Hylocomiaceae (Musci) from the Himalayas. Nova Hedwigia 49: 323-332.

Ochy RA, R. (1990). A new species of Brachythecium (Musci, Brachytheciaceae) from Nepal. Polish Bot. Stud. 1: 35-43.

Redfearn, P. L., JR., TAn, B. C. \& He, S. (1996). A newly updated and annotated checklist of Chinese mosses. J. Hattori Bot. Lab. 79: 163-357.

Received 8 May 2007; accepted for publication 27 June 2007 